Jahangirnagar University J. Biol. Sci. 7(1): 65-71, 2018 (June)

\title{
Abundance, distribution and population dynamics of Bemisia tabaci on brinjal and tomato
}

\author{
M. M. H. Khan* and I. Hossain \\ Department of Entomology, Patuakhali Science and Technology University, Dumki, \\ Patuakhali-8602, Bangladesh
}

\begin{abstract}
In order to study the abundance, distribution and population dynamics of whiteflies (Bemisia tabaci Genn) in the agriculture farm and homestead garden of Patuakhali Science and Technology University (PSTU) campus and farmer's field, brinjal and tomato plants were selected as study materials. Results revealed that the highest number of whitefly/plant (3.43) was recorded in brinjal at farmer's field followed by PSTU farm (1.13) while lowest was in homestaed gardem (1.00) than tomato. The highest percentage of plant attacked per plot by whitefly was recorded in brinjal (16.67\%/plot) while the lowest percentage was in tomato (9.76\%/plot). The highest mean percentage of $B$. tabaci adult was observed in the middle canopy (64\%) while the lowest was in lower canopy. The highest percent plant attacked (56.25\%/plot) was recorded on $2^{\text {nd }}$ March while the lowest attacked $(9.09 \% /$ plot $)$ was recorded on $15^{\text {th }}$ February. The similar trend was also found in case of tomato. The highest percent plant attacked (56.25\%/plot) was recorded on $2^{\text {nd }}$ March followed by $1^{\text {st }}$ April (50\%/plot) and 17 March (33.33\%/plot) while the lowest attacked (9.09\%/plot) was recorded on $15^{\text {th }}$ February followed by $30^{\text {th }}$ January $(10.98 \% /$ plot $)$.
\end{abstract}

Key words: Brinjal, tomato, Bemisia tabaci, distribution, population dynamics.

\section{INTRODUCTION}

The whitefly (Bemisia tabaci Gennadius) (Hemoptera: Aleyrodidae) was described over 100 years ago as a pest of tobacco in Greece (Anonymous 1989). Since then, it has become one of the most important sucking pests of world's industrial and food crops like cotton, sunflower, melon, tomato, brinjal etc. Over 500 plant species from Asia, Africa, America, Europe, Russia, Australia and the Pacific Islands confirms its polyphagous nature. The population of every species has a different host range and difference in growth and reproduction arising from rearing on different host plants (Coudriet et al., 1985, Gerling et al., 1986). The developmental time of B. tabaci from egg to adult was significantly different according to the host plant that feeds on it (Coudriet et al., 1985). It causes severe damage to cotton, mungbean, soybean, okra, brinjal and other cultivated crops by feeding on sap, secreting honeydew and transmitting virus diseases (Jose \& Usha, 2003). Both nymphs and adults of whitefly suck the cell sap from different parts of the plant causing loss of plant vigour and reduces crop yield (Attique et al., 2003). It also secretes honeydew on which black sooty mold grows, reducing the photosynthetic capabilities of plants. It acts as a sole vector of more than 100 plant viruses, which cause

\footnotetext{
* Corresponding author. Email: mohasin1965@pstu.ac.bd
} 
diseases to many commercial crops in different parts of the world (Jones 2003, Atwal \& Dhaliwal, 2007). The distribution of B. tabaci larvae varied among the three-leaf strata of the brinjal plants. This was mainly due to the behaviour of whitefly adults that laid their eggs on the underside of leaves especially on the upper stratum. McAuslane (1995) reported that the eggs were scattered all over the leaf either singly or in cluster. The immature stages lived on the underside of brinjal leaves. The first instar larvae moved a few distance around the surface of leaf. They then became sessile and fed on the plant sap until they turned to pupae. Since the shoot of a brinjal plant was the preferential oviposition sites of B. tabaci, only adults and eggs were found on the upper stratum of the plant, followed by the first larval instar in the middle stratum, the last larval instar in the lower stratum and lastly the empty pupa on the oldest brinjal leaves. Thus, the major part of the larvae III and larvae IV were concentrated in lower stratum of the plant with leaves of a specific age. By restricting the sampling in this region, efficiency in sampling could be increased. Considering above facts the present study was undertaken to know the abundance, distribution and population dynamics of B. tabaci on brinjal and tomato.

\section{MATERIALS AND METHODS}

The study was conducted in the experimental farm and homestead vegetable gardens of Patuakhali Science and Technology University (PSTU) campus, adjacent farmer's field and entomology laboratory from November 2013 to April 2014. In order to study the abundance, distribution and population dynamics of whiteflies (B. tabaci Genn), brinjal and tomato plants were selected as study materials. The abundance of whitefly were done by counting the population of insect pests on five randomly selected plants grown in three plots of $4.5 \mathrm{~m} \times 3.0 \mathrm{~m}$ sizes without employing any insecticidal plant protection measures. The observation of whitefly was recorded at weekly intervals during morning hours between 6:30 AM and 8:30 AM. The population of whiteflies (nymphs and adults) were recorded from three leaves one each from the upper, middle and lower position on five randomly selected plants. The population was counted only on five leaves and the whitefly population was expressed on per plant basis. The data were compiled and tabulated in proper form and were subjected to Microsoft Excell program for graphical presentation.

\section{RESULTS AND DISCUSSION}

Abundance of $B$. tabaci on two host plant at three locations: Figure 1 reveals variation in the mean number of whitefly population per plant (1.00 to 3.43) in brinjal and (1.00) in tomato at three locations during study period. The highest number of whitefly/plant (3.43) was recorded in brinjal at farmer's field followed by PSTU farm (1.13) while lowest was in homestaed garden (1.00). In case of tomato, the mean number of whitefly population/plant was found the same (1.00) at all locations (Fig.1). The highest attack rate of whitefly on brinjal is more than tomato for both feeding and oviposition in a multiple crop experimental area. The variation in population density of the whitefly was an obvious factor of leaf structures. Similar observation was previously reported by Khan et al. (2011). 


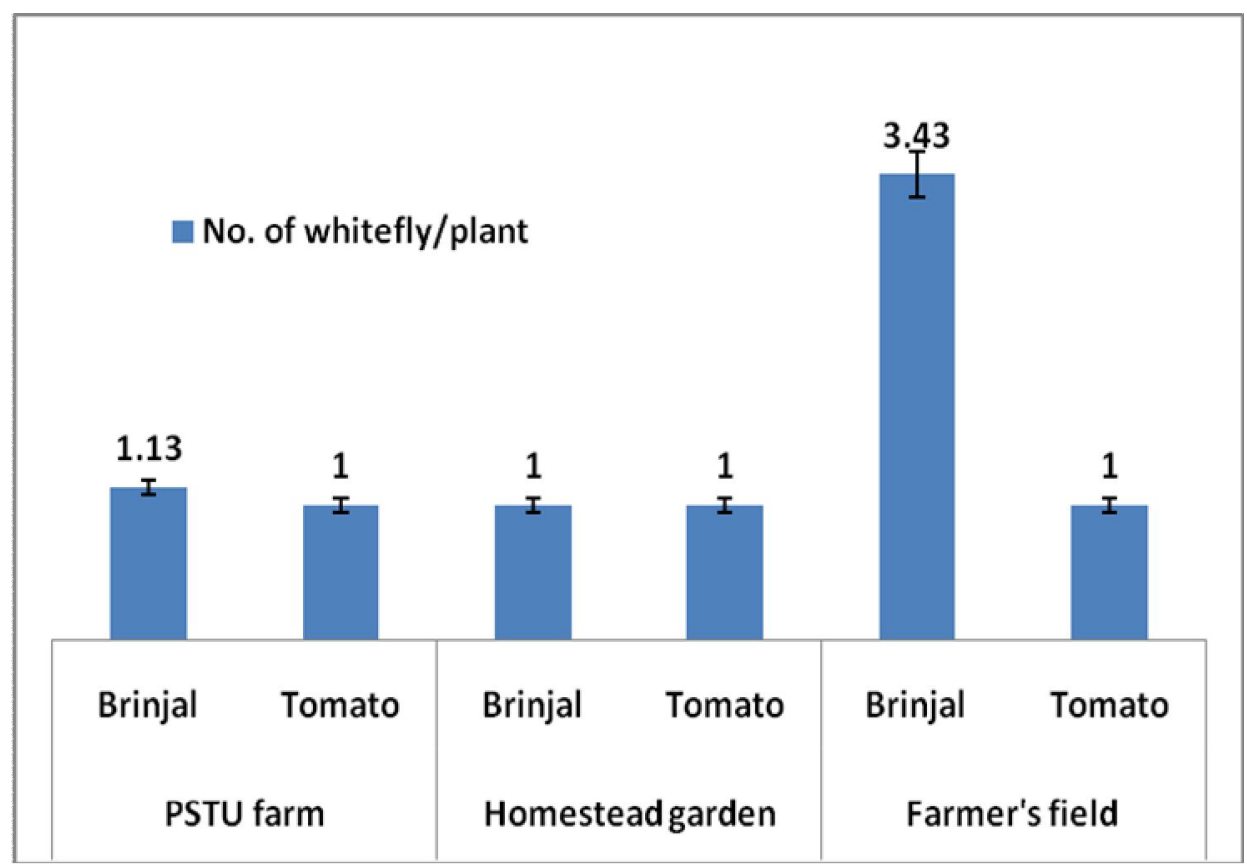

Fig. 1. Mean number of $\mathrm{B}$. tabaci per plant on two host plants in mono culture habitat at each of three locations

Distribution of $B$. tabaci adult at different canopies in brinjal plant: Figure 2 reveals that the highest mean percentage of distribution of $B$. tabaci adult was distributed in the middle canopy (64\%) followed by upper canopy (23\%) while the lowest population (13\%) distributed was in lower canopy. The host plant architecture may contribute in host plant selection by the whiteflies. It was reported that soybean whitefly has a strong preference for hairy-leaf varieties of cotton and less preference for glabrous-leaf varieties (McAuslane ,1996). It might be the reason of the presence of trichomes on the leaf surface of the host plant. Both the brinjal and tomato leaves were furnished with trichomes on both abaxial and adaxial surfaces when compared to chilli leaves (Khan et al., 2011). They also observed that adult whiteflies preferably oviposit on brinjal $S$. malagna leaves which were furnished with more and thick trichomes.

Naranjo \& Flint (1995) found that adults were consistently more abundant on main stem leaves from the top stratum of cotton plants than on the main stem leaves from the middle and lower strata. The result of present study is contradicted with the findings of Naranjo \& Flint (1995), but is similar with the findings of Krishna Lingappa (1992) who found that nymphal and pupal population was more on the middle leaves than on extreme leaves and also with the findings of Rao et al. (1991) while they reported that the middle leaves, however, harboured significantly larger nymph numbers (98.3\%). Khalid et al. (2006) studied the effects of plant height, plant maturity and climatic factors, namely sunshine duration $(\mathrm{h} / \mathrm{d})$, wind speed $(\mathrm{km} / \mathrm{h})$, rainfall amount $(\mathrm{mm} / \mathrm{d})$ and relative humidity $(\%)$ on 
the population abundance of whitefly, B. tabaci on chilli. They found that the adult whitefly preferred the leaves at the upper stratum than at the middle and lower strata.

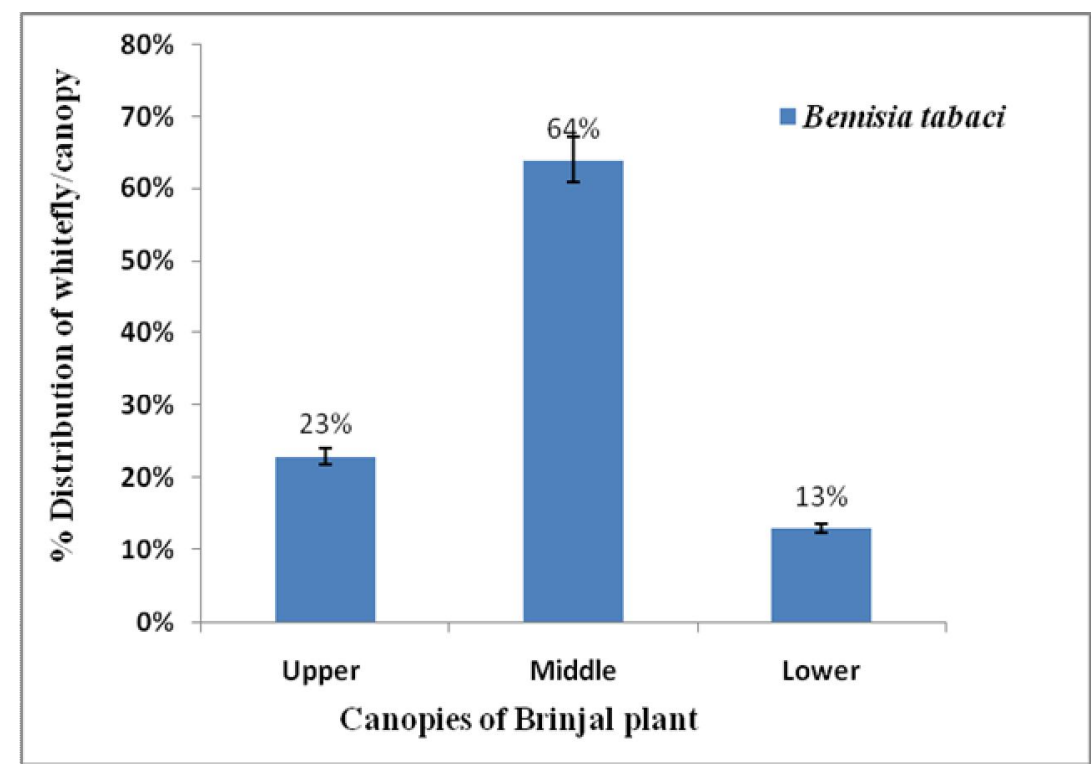

Fig. 2. Distribution of B. tabaci adult at different canopies of brinjal plant in farmers' field

Population dynamics of $B$. tabaci per five leaves on two host plant: The data on incidence of $B$. tabaci per five leaves on brinjal host revealed that the infestation of whitefly commenced after $15^{\text {th }}$ January and the highest incidence (3.54/5 leaves) was recorded on $1^{\text {st }}$ April followed by $16^{\text {th }}$ April (3.12/5 leaves), 17 March (2.51/5 leaves) and $2^{\text {nd }}$ March (2.47/5 leaves) while the lowest incidence $(1.33)$ was recorded on $15^{\text {th }}$ February followed by $30^{\text {th }}$ January (1.62/5 leaves) and $15^{\text {th }}$ January (1.76/5 leaves) (Fig. $3)$. In case of tomato, the highest incidence (1.14/5 leaves) was recorded on $15^{\text {th }}$ January followed by $2^{\text {nd }}$ March ( 0.49) while the lowest incidence (0.37/5 leaves) was on $30^{\text {th }}$ January, but no whitefly population was seen after $2^{\text {nd }}$ March and on ward (Fig. 3). The results show that brinjal was more vulnerable to attack of whitefly than tomato in different sampling dates. Setiawati et al. (2009) found that the most preferred tomato varieties for oviposition and activity of B. tabaci were Gress, Idola and BTM-855, whereas Martha, Cosmonot and Ovation were the least preferred. B. tabaci more preferred upper leaves than middle and lower leaves. None of tomato varieties was found to be resistant to gemini virus. Martha variety was relatively resistant to $\mathrm{B}$. tabaci, $\mathrm{H}$. armigera, and gemini virus with highest yield of $42.09 \mathrm{t} / \mathrm{ha}$. This variety had high density and glandular trichome secretion, thus effective in reducing B. tabaci population. The results are also supported by Khan et al. (2011). 


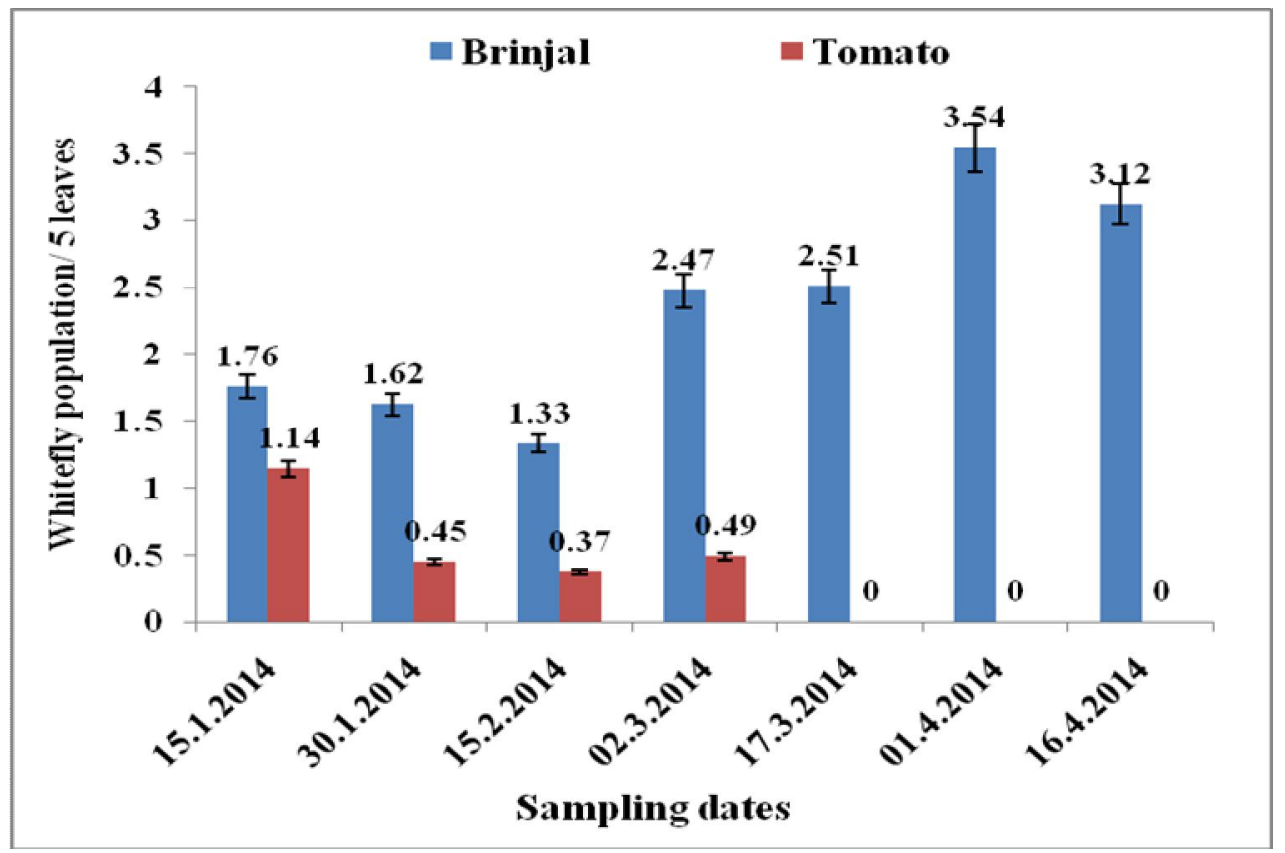

Fig. 3. Population dynamics of $B$. tabaci per five leaves on two host plant in different sampling dates at PSTU farm

Percentage of plant attacked by $B$. tabaci per plot on two host plants on different sampling dates: The data on percentage of plant attacked/plot by $B$. tabaci on brinjal host revealed that the infestation of whitefly commenced after $15^{\text {th }}$ January and the highest percent plant attacked (56.25\%/plot) was recorded on $2^{\text {nd }}$ March followed by $1^{\text {st }}$ April (50\%/plot) and 17 March (33.33\%/plot) while the lowest attacked (9.09\%/plot) was recorded on $15^{\text {th }}$ February followed by $30^{\text {th }}$ January (10.98\%/plot) (Fig. 4). In case of tomato, the highest attacked $\left(8.76 \% /\right.$ plot) was recorded on $15^{\text {th }}$ January followed by $30^{\text {th }}$ January $(1.79 \% /$ plot $)$ and $2^{\text {nd }}$ March (1.79\%/plot) while the lowest attacked (1.67\%/plot) was on $15^{\text {th }}$ February, but no attack of whitefly population was seen after $2^{\text {nd }}$ March and on ward (Fig. 4). Likewise incidence, the results show that brinjal was more vulnerable to attack of whitefly than tomato in different sampling dates. This might be due to variable climatic conditions of that particular region and time of cultivation that particular crop. The results are supported by Khan et al. (2011). 


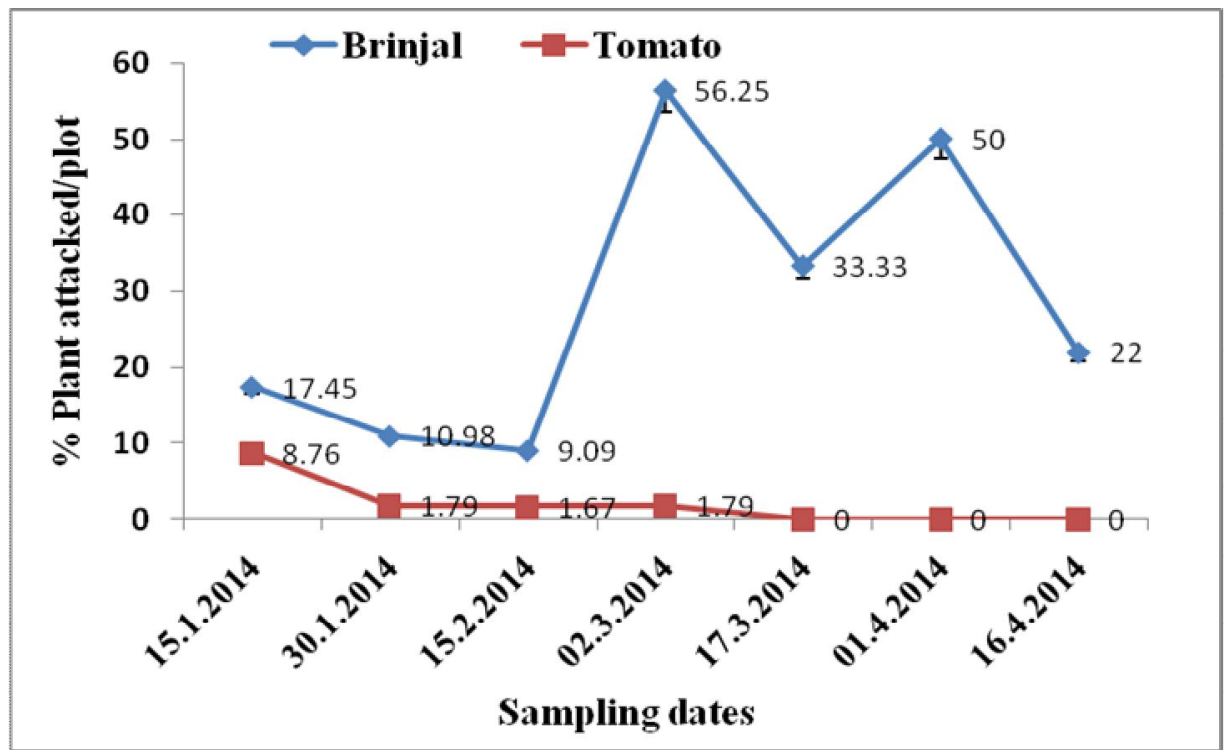

Fig. 4. Mean percentage of plant attacked per plot by B. tabaci on brinjal and tomato hosts in different sampling dates at PSTU farm

From the findings of the present research work it can be concluded that among three habitats, farmer's field grown brinjal plants harbour more whitefly population as compared to plants grown in PSTU farm and homestead garden. The highest percent of whitefly population was distributed in middle canopy as compared to upper and lower canopies.

\section{REFERENCES}

Anonymous, 1989. Management of Whitefly, Bemisia tabaci G. on Cotton, p: 50. Andhra Predesh Agriculture University, Rajendranagar, Hyderabad.

Attique, M. R., Rafiq, M., Ghaffar, A., Ahmad, Z. and Mohyuddin, A. I. 2003. Hosts of Bemisia tabaci (Gen.) (Homoptera; Aleyrodidae) in cotton areas of Punjab, Pakistan. Crop Prot. 22(5): 715-720.

Atwal, A. S. and Dhaliwall, G. S. 2007. Agricultural pests of south Asia and their management. Kalayani Publishers, New Delhi, India, 505.

Coudriet, D. L., Prabhaker, N., Kishara, A. N. and Meyerdirk, D. E. 1985. Variation in development rate on different hosts and overwintering of the sweetpotato whitefly Bemisia tabaci (Homoptera: Aleyrodidae). Environ. Entomol. 17: 516-519.

Gerling, D., Horowitz, A. R. and Baumgartner, J. 1986. Autecology of Bemisia tabaci. Agric. Ecosys. Environ. 17: 5-19.

Jones, D. R.. 2003. Plant viruses transmitted by whiteflies. European J. Plant Pathol. 109(3): 195219.

Jose. J. and Usha, R., 2003. Bhendi yellow vein mosaic disease in India is caused by association of a DNA beta satellite with a begomovirus. Virology. 305(2): 310-317. 
Khalid, S. A. N., Mohamad Roff, M. N., Touhidor, M. R. and Idris, A. B. 2006. Effects of plant height, maturity and climatic factors on the population of whitefly (Bemisia tabaci) on chilli (Capsicum annuum L.). J. Trop. Agric. and Fd. Sc. 34(1): 195-196.

Khan, M. R., Ghani, I. A., Khan, M. R., Ghaffar, A. and Tamkeen, A. 2011. Host plant selection and oviposition behaviour of whitefly Bemisia tabaci (Gennadius) in a mono and simulated polyculture crop habitat. Afr. J. Biotechnol. 10(8): 1467-1472.

Krishna, N. I. and Lingappa, S. I. 1992. Insect sci. Appl. (ICIPE). 13(3): 377-379.

McAuslane, H. J. 1995. Sweetpotato Whitefly B Biotype of Silverleaf Whitefly, Bemisia tabaci (Gennadius) or Bemisia argentifolii Bellows and Perring (Insecta: Homoptera: Aleyrodidae). Cooperative Extension Service, Institute of Food and Agricultural Sciences.

McAuslane, H. J. 1996. The influence of pubescence on ovipositional preference of Bemisia argentifolii (Homoptera: Aleyrodidae) on soybean. Environ. Entomol. 25: 834-84.

Naranjo, S. E. and Flint, H. M. 1995. Envir. Ent. 24: 261-270.

Rao, N. V., Reddy, A. S., Rao, B. R. and Stayanarayana, G. 1991. Intraplant distribution of whitefly, Bemisia tabaci Genn. on cotton, Gossypiom hirsutum L. J. Insect Sci. 4: 32-36.

Setiawati, W., Udiarto, B.K. and Gunaeni, N. 2009. Preference and infestation pattern of Bemisia tabaci (genn) on some totmato varieties and its effect on Gemini virus infestation. Indonesian J. Agric. Sci. 2 (1): 57-64. 